\title{
The Process of Investigation Against The Criminal Action of Narcotics
}

\author{
Feri Andriawan ${ }^{*}$, Ira Alia Maerani*) and Achmad Sulchan ${ }^{* *}$ ) \\ *) Lawyer, E-mail: nedfer123@gmail.com \\ **) Faculty of Law, Universitas Islam Sultan Agung (UNISSULA) Semarang \\ ${ }^{* * *}$ Faculty of Law, Universitas Islam Sultan Agung (UNISSULA) Semarang
}

\begin{abstract}
.
The purpose of this study is to find out the process of investigating narcotics criminals at the Pekalongan Police and to find out the obstacles and solutions faced in the process of investigating narcotics criminals at the Pekalongan Police. The type of research used in this research is normative empirical, which begins deductively with an analysis of the articles in the relevant laws and regulations. The problems examined in this study revolve around legislation and relate to their application in practice. Research results Pekalongan Resort Police The process of carrying out investigations against narcotics perpetrators is in accordance with the provisions of the Criminal Procedure Code, the obstacles are the network of narcotics abuse crimes which are easily broken in the chain, transportation facilities for investigators of the Pekalongan Police Narcotics Unit are felt to be a bit hampering, and solutions with pre-emptive efforts (coaching) and Preventive (prevention). Keywords: Criminals; Investigations; Narcotics.
\end{abstract}

\section{Introduction}

Article 28 H Paragraphs (1) and (2) of the 1945 Constitution of the Republic of Indonesia (UUD NRI 1945), that is, everyone has the right to live in physical and spiritual prosperity, to have a place to live, and to have a good and healthy living environment and have the right to obtain health services. That based on the article that everyone has the right to live in physical and spiritual prosperity, a place to live and to get an environment that does not contain narcotics. Narcotics are substances or drugs derived from plants or non-plants, both synthetic and semisynthetic, which can cause a decrease or change in consciousness, loss of taste, reduce and eliminate pain, and cause dependence. ${ }^{1}$ Narcotics can be addictive and damage the body and ruin a human's life.

Act No. 35 years $2009^{2}$ concerning Narcotics which regulates, supervises and takes action on the circulation and abuse of Narcotics. Narcotics not only make humans addicted, but can cause someone to die quickly and unnaturally. Humans really need a clean place in their environment and a healthy body in order to carry on their life. To prevent narcotics abuse, the role of the government is to establish law enforcement, one of which is the police. The police are all matters relating to the functions and institutions of the police in accordance with the laws and regulations. The future police officer is a police figure who is able to overcome future challenges and in accordance with the development of society. The Indonesian National Police must be able to protect, protect, maintain order and

${ }^{1}$ Act No. 5 of 1997 concerning Psychotropics Article 1.

2 Act No.35 of 2009 concerning Narcotics 
provide security to the public. ${ }^{3}$ Act No. 2 of 2002 concerning the National Police of the Republic of Indonesia expands the functions and duties of the Police which include maintaining security and public order, law enforcement, protection and protection and services to the community by upholding human rights. issued Article 10 of the Criminal Code concerning the types of crimes that will be given to narcotics defendants. Narcotics abuse in Indonesia in recent years has become a serious problem and has reached an alarming state, so that the drug problem has become a national problem ${ }^{4}$.

Narcotics are the nation's enemy in giving birth to the next generation of the nation that is healthy and free from narcotics. Narcotics with the use of large doses can be intoxicating and addictive. Therefore, narcotics crime has become a promising and rapidly growing business, where this activity has an impact on mental damage, both physically and psychologically for narcotics users, especially the younger generation. Drug abuse has been carried out by all elements of society. From law enforcement officials, political officials, private officials, students, children.

The production and circulation of narcotics is increasingly circulating in the midst of society, with the shrewdness of the role of the narcotics mafia as if it cannot be overcome. The narcotics mafia has poisoned law enforcers and the public as users and as dealers in Indonesia and various parts of the world. ${ }^{5}$.

Narcotics crime which has long been an enemy of the nation, narcotics have been very worrying for every nation and all nations in the world today. Every nation must have law enforcement, but until now narcotics cases have never stopped and every year there are always narcotics cases, especially in Indonesia.

According to the National Narcotics Agency in 2020, narcotics crime is an extraordinary crime that is a concern for all countries in the world, because narcotics can damage a generation of people from a country. Currently, the world is being hit by the COVID-19 pandemic, which affects all systems and joints of human life, even causing millions of people to die. The COVID-19 pandemic has also had a major impact on the emergence of new modes of illicit drug trafficking in the world. In the 2020 UNODC World Drug Report, it was recorded that around 269 million people in the world abuse drugs (study in 2018). This number is 30\% more than in 2009 with the number of drug addicts recorded at more than 35 million people (The Third Booklet of the World Drugs Report, 2020). UNODC also released a global phenomenon where as of December 2019 it was reported that more than 950 types of new substances had been found. Meanwhile in Indonesia, based on data from the National Narcotics Agency Laboratory, so far, 83 NPS have been successfully detected, of which 73 NPS have been included in the Minister of Health Regulation No. 22 of 2020. In 2020 BNN has succeeded in mapping 92 narcotics syndicate networks, as many as 88 syndicate networks. It has been

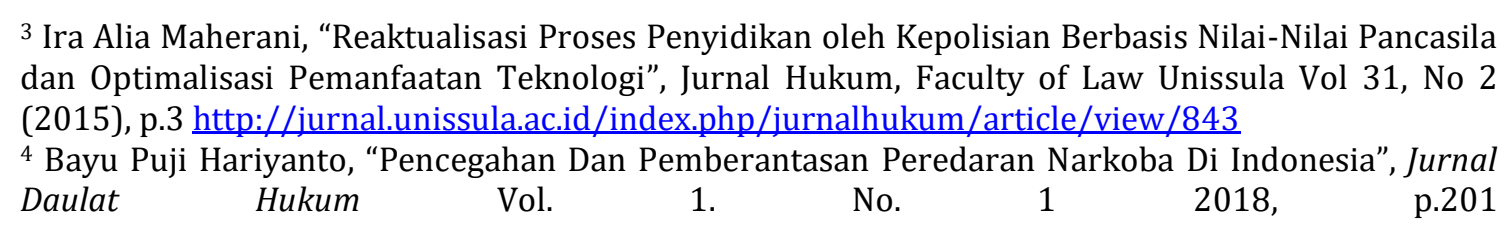
http://jurnal.unissula.ac.id/index.php/RH/article/view/2634

${ }^{5}$ Sudanto, 2015. Penerapan tindak Pidana Narkotika. ADIL: Jurnal Hukum Vol. 7 No.1 
successfully revealed that 14 of them are international syndicate networks, and there are at least 27 prison residents from all over Indonesia who are actively involved in controlling narcotics from within prisons. BNN managed to uncover 806 narcotics crime cases with a total of 1247 suspects. Several pieces of evidence were confiscated, including: 12 tons of methamphetamine, 2.36 tons of marijuana leaves, and 340,357 pills of ecstasy. In 2020, BNN has also destroyed marijuana fields with a total area of 30.5 hectares and evidence of 213,045 marijuana plants. The assets that were successfully confiscated from the TPPU for narcotics cases in 2020 reached IDR 86,022,409,8176.

The case found by the Perkalongan Police is now successfully arresting the drug dealers. From the hands of the perpetrators, officers confiscated evidence of a number of packages of dried marijuana ready to be distributed. The suspect is MT alias snail, a resident of Legokkalong Village, Karanganyar, Pekalongan Regency. Conch hid evidence of marijuana packages ready for distribution in the air vents of his house. The police confiscated a folded newspaper containing 10 packages of dried marijuana leaves ready for distribution wrapped in transparent plastic clips. As well as another folded newspaper containing dried marijuana leaves that are not yet in the package. The Head of the Narcotics Unit at the Pekalongan Police has succeeded in disclosing the suspect's arrest, with information from the public about people circulating marijuana-type narcotics. After the information was investigated by the police, the officers finally managed to secure the alleged perpetrator at his home without a fight. For his actions, the suspect MT alias Keong is suspected of violating Article 114 number 35 of 2009 concerning narcotics. MT is threatened with a minimum imprisonment of 5 years and a maximum of 20 years ${ }^{7}$. Narcotics abuse has been qualified as a criminal act which was originally regulated in Act No. 22 of 1997. In contrast to Act No. 22 of 1997, there are new provisions, especially regarding narcotics abusers in Act No. 35 of 2009. Article 1 of Law Act No. 35 of 2009 states that an abuser is a person who uses narcotics without rights or against the law ${ }^{8}$.

The purpose of this study was to determine and analyze the process of investigating narcotics criminals at the Pekalongan Police and the obstacles and solutions faced in the process of investigating narcotics criminals at the Pekalongan Police.

\section{Research Methods}

The approach method used in this research is: Normative legal research includes research on legal principles, level of legal synchronization. The research approach used is empirical juridical research, namely a research approach that can be observed in real life. The type of research used in completing this thesis is

\footnotetext{
${ }^{6}$ www.bnn.go.id

7 https://www.kompas.tv/article/177266/polres-pekalongan-catch-pengedar-narkoba Accessed on February 2021

8Dafit Supriyanto Daris Warsito, "Sistem Pemidanaan Terhadap Pelaku Tindak Pidana Penyalahguna Narkotika", Jurnal Daulat Hukum Vol. 1. No. 1 2018, http://jurnal.unissula.ac.id/index.php/RH/article/view/2562
} 
descriptive research method, namely research conducted by examining library materials (secondary data) or library law research. ${ }^{9}$.

This research using secondary data obtained through the literature. The research materials used include primary legal materials, secondary legal materials and tertiary legal materials. Primary legal materials are binding legal materials, which include statutory regulations related to the topics discussed including (1) the Qur'an, (2) Al-hadists, (3) Act No. 35 of 2009 concerning Narcotics, (4) Act No. 2 of 2002 concerning the National Police of the Republic of Indonesia Police, (5) Government Regulation of the Republic of Indonesia number 2 of 2003 concerning Disciplinary Regulations for Members of the Indonesian National Police, (6) Criminal Code, Secondary legal materials are non-binding legal materials that provide an explanation of primary legal materials which are the findings of the opinions or thoughts of experts or experts who study a particular field in particular that will provide directions to researchers including legal books, journals, letters decisions from district courts and the Internet, Tertiary legal materials are legal materials that can provide explanations for primary legal materials and secondary legal materials. The tertiary legal materials are narcotics data from the internet. The data collection technique of this research is the library. This study uses Library Research, namely the collection of data obtained from literary sources, scientific works, legislation and other written sources related to the problem under study as a theoretical basis.

The data that has been collected through data collection activities is then processed and ready to be presented in the form of a narrative which is then analyzed qualitatively.

\section{Results and Discussion}

\subsection{The process of investigating narcotics cases carried out by the Pekalongan Resort Police}

Law enforcement is an activity to harmonize the relationship of values outlined in the rules, solid views and manifest them in attitudes, act as a series of value elaborations at the final stage to create peaceful social life. ${ }^{10}$ The problem of law enforcement in Indonesia includes three things, including the culture of the community where legal values will be enforced, the structure of law enforcement officers and finally the substance of the law that will be enforced. The purpose of being enforced by law is to prevent acts of vigilantism to the community. The community must be continuously provided with legal counseling to comply with the law, even though there may be acts of violence judge himself by the community as a result of his weakness law enforcement ${ }^{11}$. Law enforcement, of course, cannot be separated from the matter of officials who occupy strategic positions as law

\footnotetext{
9 Hera Saputra, Munsharif Abdul Chalim, "Penerapan Sistem Pemidanaan Terhadap Pelaku Tindak Pidana Penyalahgunaan Narkoba (Studi Kasus di Polda Jateng)", Jurnal Daulat Hukum Vol. 1. No. 1 2018

${ }^{10}$ Soekanto, Soerjono, (1983), Hukum Adat Indonesia, Jakarta: PT. Raja Grafindo Persada, p.3

${ }^{11}$ Hatta G.R., (2009), Pedoman Manajemen Informasi Kesehatan Di Sarana Pelayanan Kesehatan, Jakarta: UI-Press, p.32
} 
enforcers, namely the Police, Prosecutors and Judges, which are limited to professional matters. ${ }^{12}$.

The procedure for investigation is: (a) Investigators in conducting investigations are required to show identification. (b). Investigators are coordinated, supervised, and given instructions by investigators from the state police of the Republic of Indonesia ${ }^{13}$. The National Police of the Republic of Indonesia as one of the organizers of government activities in the field of law enforcement that protects and protects the community does not have an easy task, because the scope of the police's duties is very broad, namely the entire community, and the development of community progress is quite rapid, resulting in changes in the demands of services to the public community in all fields, including police services to the community ${ }^{14}$.

The investigation is carried out after the preliminary investigation stage, namely a series of investigator actions to seek and find an event that is suspected of being a criminal act ${ }^{15}$ in order to determine whether or not an investigation can be carried out according to the method regulated by law. All state police officers without exception have been involved in investigative tasks, which in essence is one of the many tasks specified in Act No. 8/1981 on the Criminal Procedure Code, which is closely related with other duties, namely as an entire effort by law enforcers to make someone who is a perpetrator of a crime must be held accountable for his behavior according to criminal law before a judge. ${ }^{16}$

The stages of the narcotics case investigation process carried out by the Pekalongan Resort Police include (1) the investigation process, namely the perpetrator was caught red-handed that the perpetrator had, stored, controlled methamphetamine and had consumed methamphetamine-type narcotics and the officers found some evidence that allegedly belonged to the perpetrator so that investigators can continue their investigations, (2) The process of prosecution after the perpetrator is caught, then the investigator detains the perpetrator for the purposes of the investigation process. After the perpetrator was detained, the officers searched the place where the perpetrator was caught and the officers found some evidence: The first case of narcotics in the form of methamphetamine was stored in a wallet and in a lighter, two packages of methamphetamine wrapped in a plastic matchstick wrapper, one black Oppo brand cellphone, one bong or suction device, in the second case 12 packages containing 8.15 grams of methamphetamine, a meth or bong suction device, 5 gas lighters, 1 bowl and one empty pack of Gudang Garam Surya cigarettes. He added that the modus operandi

\footnotetext{
12 Barda Nawawi, Arief, 2001, Masalah Penegakan Hukum Dan Kebijakan Penanggulangan Kejahatan, Bandung: Citra Aditya Bakti, p.34

${ }^{13}$ Taufik Makarao, 2010, Hukum Acara Pidana Dalam Teori dan Praktek. Jakarta: Ghalia, p. 24-25.

14 Mulyadi, 2007, Kompilasi Hukum Pidana Dalam Perspektif Teoritik Dan Praktik Peradilan Perlindungan Korban Kejahatan, Sistem Peradilan Dan Kebijakan Pidana, Filsafat Pemidanaan Serta Upaya Hukum Peninjauan Kembali Oleh Korban Kejahatan, Bandung: CV. Mandar Maju, p.40 15 Chuasanga A., Ong Argo Victoria, "Legal Principles Under Criminal Law in Indonesia and Thailand", Jurnal Daulat Hukum, Vol $2, \quad$ No 1 (2019) http://jurnal.unissula.ac.id/index.php/RH/article/view/4218

${ }_{16}$ Lamintang and Theo Lamintang, 2010, Hukum Penitensier Indonesia; Second edition, Sinar Grafika, Jakarta, p.47.
} 
was being caught, storing and possessing methamphetamine, then the items were confiscated by the Pekalongan Resort Police. against suspects related to possession of objects suspected of being narcotics, and investigators conduct examinations of witnesses who were at the scene of the case (TKP) when the suspect was arrested, (4) The process of making the examination case file is made after the investigation process, investigations and investigations have been completed. And then it can be delegated to the Prosecutor's Office for further processing.

The process of carrying out investigations against perpetrators of narcotics abuse at the Pekalongan Resort Police is carried out in accordance with the provisions of the Criminal Procedure Code and the suspect has been proven to have committed an act, namely any person who without rights or against the law, possesses, keeps, controls or provides Narcotics Category 1 which is not a plant and or any abuser of Class 1 Narcotics. I for oneself, as referred to in the Primary formulation of Article 112, Subsidiary Article: 127 of Act No. 35 of 2009 concerning Narcotics.

\subsection{Obstacles Investigators Meet in the Investigation Process of Narcotics Perpetrators}

The obstacles faced by the Pekalongan Resort Police Investigators in conducting the investigation process against narcotics perpetrators are the lack of community participation, although there has been participation in providing information on the occurrence of narcotics crimes, but it is still felt to be lacking and the participation needs to be increased, in addition to those mentioned above, are regarding investigations which sometimes experience difficulties because the chain of criminal acts of narcotics abuse is easily broken. The Narcotics Unit of the Pekalongan Police hopes that with the instrument of Article 131 of Act No. 35 of 2009 concerning Narcotics, it is hoped that public participation in providing information on complaints of narcotics crimes in the Pekalongan Law area can increase.

Obstacles other than those mentioned above are related to investigations, which sometimes experience difficulties because the chain of criminal acts of narcotics abuse is easily broken. So, it takes foresight from law enforcement officials in eradicating narcotics networks to their roots. For transportation facilities for investigators of the Pekalongan Police Narcotics Unit, it is felt to be a bit hampering because sometimes there is still a lack of operational funds, even though the provision of vehicle facilities for the investigators of the Drug Investigation Unit is carried out on a priority basis. The Pekalongan Police Narcotics Unit requires more sophisticated information technology equipment to uncover narcotics networks that have been using advanced technology as well.

\section{Conclusion}

The investigation process for narcotics cases carried out by the Pekalongan Resort Police included the investigation process, namely the perpetrator was caught red-handed that the perpetrator had, stored, controlled methamphetamine and had consumed methamphetamine type narcotics and the officers found some 
evidence that allegedly belonged to the perpetrator so that investigators could continue their investigation. After the perpetrator is caught, the investigator then detains the perpetrator for the purposes of the investigation process. After the perpetrator is detained, the officer conducts a search. The examination process is by conducting further examination at the place where the suspect of the narcotics crime was arrested, the investigator conducts an examination of the suspect related to the ownership of objects suspected of being narcotics, and investigators conduct examinations of witnesses who were at the scene of the case (TKP) when the suspect was arrested, and the process of making examination case files is made after the investigation, prosecution and examination processes have been completed. And then it can be delegated to the Prosecutor's Office for further processing. The obstacle in carrying out the investigation process is because the network of criminal acts of narcotics abuse is easily broken. So, it takes foresight from law enforcement officials in eradicating narcotics networks to their roots. For transportation facilities for investigators of the Pekalongan Police Narcotics Unit, it is felt to be a bit hampering because sometimes there is still a lack of operational funds, even though the provision of vehicle facilities for the investigators of the Drug Investigation Unit is carried out on a priority basis. The Pekalongan Police Narcotics Unit requires more sophisticated information technology equipment to uncover narcotics networks that have been using advanced technology. Efforts made to overcome obstacles in the investigation of Narcotics cases include: Preemptive (coaching) Police held activities with the aim of eliminating the reasons for the opportunities and incentives for Narcotics perpetrators to commit narcotics crimes. and Preventive (prevention) to prevent the occurrence of narcotics crimes through control and supervision with adequate means and facilities Geographic Information System in Pekalongan City with Global Mapper and Google Integration Earth.

\section{References}

\section{Journals:}

[1] Bayu Puji Hariyanto, "Pencegahan Dan Pemberantasan Peredaran Narkoba Di Indonesia”, Jurnal Daulat Hukum Vol. 1. No. 1 2018, p.201 http://jurnal.unissula.ac.id/index.php/RH/article/view/2634

[2] Chuasanga A., Ong Argo Victoria, "Legal Principles Under Criminal Law in Indonesia and Thailand", Jurnal Daulat Hukum, Vol 2, No 1 (2019) http://jurnal.unissula.ac.id/index.php/RH/article/view/4218

[3] Dafit Supriyanto Daris Warsito, "Sistem Pemidanaan Terhadap Pelaku Tindak Pidana Penyalahguna Narkotika”, Jurnal Daulat Hukum Vol. 1. No. 1 2018, http://jurnal.unissula.ac.id/index.php/RH/article/view/2562

[4] Hera Saputra, Munsharif Abdul Chalim, "Penerapan Sistem Pemidanaan Terhadap Pelaku Tindak Pidana Penyalahgunaan Narkoba (Studi Kasus di Polda Jateng)", Jurnal Daulat Hukum Vol. 1. No. 1 2018, http://jurnal.unissula.ac.id/index.php/RH/article/view/2630

[5] https://www.kompas.tv/article/177266/polres-pekalongan-catchpengedar-narkoba 
[6] Ira Alia Maherani, "Reaktualisasi Proses Penyidikan oleh Kepolisian Berbasis Nilai-Nilai Pancasila dan Optimalisasi Pemanfaatan Teknologi", Jurnal Hukum, Faculty of Law Unissula Vol 31, No 2 (2015), p.3 http://jurnal.unissula.ac.id/index.php/jurnalhukum/article/view/843

[7] Sudanto, 2015. Penerapan tindak Pidana Narkotika. ADIL: Jurnal Hukum Vol. 7 No.1

\section{Books:}

[1] Barda Nawawi, Arief, 2001, Masalah Penegakan Hukum Dan Kebijakan Penanggulangan Kejahatan, Bandung: Citra Aditya Bakti

[2] Hatta G.R., 2009, Pedoman Manajemen Informasi Kesehatan Di Sarana Pelayanan Kesehatan, Jakarta: UI-Press

[3] Lamintang and Theo Lamintang, 2010, Hukum Penitensier Indonesia; Second edition, Sinar Grafika, Jakarta.

[4] Mulyadi, 2007, Kompilasi Hukum Pidana Dalam Perspektif Teoritik Dan Praktik Peradilan Perlindungan Korban Kejahatan, Sistem Peradilan Dan Kebijakan Pidana, Filsafat Pemidanaan Serta Upaya Hukum Peninjauan Kembali Oleh Korban Kejahatan, Bandung: CV. Mandar Maju.

[5] Soekanto, Soerjono, (1983), Hukum Adat Indonesia, Jakarta: PT. Raja Grafindo Persada

[6] Taufik Makarao, 2010, Hukum Acara Pidana Dalam Teori dan Praktek. Jakarta: Ghalia.

\section{Internet}

[1] www.bnn.go.id

[2] https://www.kompas.tv/article/177266/polres-pekalongan-catchpengedar-narkoba. Accessed February 20, 2021

\section{Regulation:}

[1] Act No. 5 of 1997 concerning Psychotropics

[2] Act No.35 of 2009 concerning Narcotics 